\title{
Topographic and refractive findings in osteogenesis imperfecta
}

\section{Osteogenezis imperfektada topografik ve refraktif bulgular}

\author{
Işılay ÖZSOY KOYUN ${ }^{1 \oplus}$, Aylin ARDAGiL AKÇAKAYA², Burak ŞiMŞEK ${ }^{3}$, Ayla GÜVEN ${ }^{4}$, Efe KOYUN ${ }^{1}$
}

\section{ABSTRACT}

Aim: To research ocular findings in patients with osteogenesis imperfecta (OI).

\begin{abstract}
Methods: Patients were grouped according to the type of OI. Age and gender data were noted. Refraction, intraocular pressure (IOP), and central corneal thickness (CCT) values were measured. Corneal topography images were obtained. Fundus examinations were made in all patients. Best corrected visual acuity (BCVA) and spherical equivalent (SE) values were recorded. Data about patients' scleral color changes were noted.
\end{abstract}

Results: In this study, 30 eyes from 15 patients were examined. Of the 15 patients, 8 had Ol Type 1, 5 had Ol Type 4, and 2 couldn't be classified by Sillence's classification. One of these patients had a FKBP10 and the other a WNT1 mutation. The minimum CCT was $397 \mu \mathrm{m}$ and maximum was $588 \mu \mathrm{m}$. Average CCT was 492 \pm 67.49 $\mu \mathrm{m}$. Corneal apex keratometry (K) and corneal astigmatism values were higher for the OI Type 4 group than Type 1 ( $p<0.01, p<0.05$, respectively). BCVA values were significantly higher in the OI Type 1 group than the OI Type $4(p=0.002)$ Out of 30 eyes, 8 had blue sclera (26.7\%). All of the patients with blue sclera had OI Type 1. There was no significant difference in terms of CCT, posterior elevation values, or corneal astigmatism values between patients with and without blue sclera ( $p>0.05)$. Corneal apex $K$ value was statistically lower in the patients with blue sclera $(p<0.05)$.

Conclusion: Our findings in patients with Ol included thinner CCT, blue sclera, steep $K$ values especially in Type 4 group. So patients should be followed regularly for keratoconus. Because of corneal thinning, physicians must be aware of underestimation of IOP. Patients and their relatives should be advised to use protective glasses for probable trauma.

Keywords: Osteogenesis imperfecta, keratoconus, blue sclera, topography, refraction
Öz

Amaç: Osteogenezis imperfekta hastalarında oküler bulguları incelemek amaçlanmıştır.

Yöntemler: Hastalar Osteogenezis imperfekta (OI) tiplerine göre gruplandırıldı. Yaş ve cinsiyetleri not edildi. Refraksiyon, göz içi basıncı (GiB) santral korneal kalınlık (SKK) değerleri ölçüldü. Korneal topografi görüntüleri alındı. Tüm hastaların fundus muayeneleri yapıldı. Sferik eşdeğerleri ve en iyi düzeltilmiş görme keskinlikleri (EDGK) kaydedildi. Hastalarda skleral renk değişikliği olup olmadığı not edildi.

Bulgular: Bu çalışmada, 15 hastanın 30 gözü incelenmiştir. On beş hastanın 8'i Tip 1 OI, 5'i Tip 4 Ol ve 2'si de Sillence sınıflandırma sistemine göre sınıflandırılamadı. Sınıflandırılamayan hastaların birinde FKBP10 mutasyonu ve diğerinde WNT1 mutasyonu vardı. Santral korneal ka-

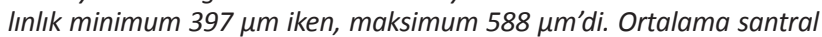
korneal kalınlık 492 $667,49 \mu m^{\prime} d i$. Korneal apeks keratometri (K) ve korneal astigmatizma değerleri Tip 4 OI grubunda Tip 1 Ol grubuna göre daha yüksek bulunmuştur (sırasıyla $p<0,01, p<0,05$ ). EDGK Tip 1 Ol grubunda Tip 4 Ol grubuna göre anlamlı olarak daha yüksek bulunmuştur $(p<0,01)$. Çalışmaya alınan 30 gözden 8'inde mavi sklera saptanmıştır $(\% 26,7)$. Mavi sklerası olan hastaların tamamı Tip 1 OI hastasıdır. Mavi sklerası olan ve olmayan hastalar arasında SKK, posterior elevasyon veya korneal astigmatizma değerleri açısından anlamlı fark saptanmamıştır $(p>0,05)$. Korneal apex $K$ değerleri mavi sklerası olan hastalarda istatistiksel anlamlı derecede düşüktü $(p<0,05)$.

Sonuç: Ol hastalarında bulgularımız daha ince SKK, mavi sklera ve özellikle Tip 4 OI hastalarında dik K değerleridir. Bu nedenle hastalar keratokonus açısından düzenli takip edilmelidir. Ince SKK nedeniyle yalancı göz içi basıncı düşüklüğüne karşı dikkatli olunmalıdır. Olası bir travmaya karşı hasta ve hasta yakınlarına koruyucu gözlük kullanımı önerilmelidir.

Anahtar kelimeler: Osteogenesis imperfekta, keratokonus, mavi sklera, topografi, refraksiyon

Received: 19.07 .2018

Accepted: 10.08 .2018

${ }^{1}$ Department of Ophthalmology, Kastamonu State Hospital, Kastamonu, Turkey

${ }^{2}$ Ataköy Dünyagöz Hospital, İstanbul, Turkey

${ }^{3}$ Department of Ophthalmology, Birecik State Hospital, Şanlıurfa, Turkey

${ }^{4}$ Department of Pediatric Endocrinology, Sağlık Bilimleri University Zeynep Kamil Maternity and Children Hospital, İstanbul, Turkey

Corresponding author: Işılay Özsoy Koyun, Kastamonu State Hospital, Department of Ophthalmology, Kastamonu, Turkey

e-mail: drisilayozsoy@gmail.com

ORCID ID's:

I.Ö.K. 0000-0003-0101-1900 


\section{INTRODUCTION}

Osteogenesis imperfecta (OI) is a connective tissue disorder that occurs because of impaired collagen production and metabolism. It increases bone fragility and is accompanied by blue sclera and deafness ${ }^{1}$. It was first reported at the end of the 18th century, and in 1918, Van der Hoeve was the first to describe it as a clinical syndrome. There is no gender or racial dominance, and it has autosomal dominant inheritance. There are also rare reports of autosomal recessive and sporadic cases ${ }^{2}$. Its incidence is between $1: 15000$ and $1: 20000$, but the real incidence may be higher because of undiagnosed, mild-type cases ${ }^{3}$. Sillence classified the disease into 4 subtypes by clinical and radiological findings. OI Type 1 is mild, OI Type 2 is prenatal lethal, OI Type 3 is progressive and leads to deformities, and OI Type 4 results in moderate deformities. COLA1/COLA2 gene mutations are present in $90 \%$ of the patients. However, various new mutations have been identified; therefore, classification has recently been expanded ${ }^{5}$.

The most frequent ophthalmic finding is blue sclera. Blue sclera is seen in OI Type 1 patients but doesn't occur in OI Type 4 patients. There is a weak correlation between blue sclera and other findings of the disease ${ }^{6}$. Another important and common ocular finding in this disease is thinning in the central corneal thickness $(\mathrm{CCT})^{1,7,8}$. Other ocular findings include decreased ocular rigidity, myopia, glaucoma, keratoconus, corneal opacities, small corneal radius, congenital Bowman's layer agenesis, and posterior embryotoxon ${ }^{1,9}$. Congenital glaucoma, zonular cataract, choroidal sclerosis, subhyaloid hemorrhage, ectopia lentis, optic neuropathy, or atrophy because of compression deformities and cranial fractures are other ophthalmologic disorders that rarely occur with $\mathrm{Ol}^{9}$.

In this study, our aim was to research ocular findings in children with Ol at our hospital's pediatric clinic.

\section{MATERIAL and METHODS}

Thirty eyes of 15 patients were included in this study.
Local ethics committee approval was obtained for the study. The ethical principles of Helsinki declaration were followed during the study. All patients were examined by the same physician in the same room and at the same time of the day. Patients with history of dry eye and corneal injury, patients who used topical eye drops or contact lenses, and patients who were examined with gonioscopy were excluded from the study. Patients were divided into groups by Sillence classification. Ages and genders of the patients were noted. Firstly, $1 \%$ tropicamide and $1 \%$ cyclopentolate hydrochloride were both instilled once at 5 minute-intervals aparts, and after 30 minutes, refractive values were measured with a Canon RK-F1 autorefractometer (Canon, Tokyo, Japan). The best corrected visual acuity (BCVA) was obtained with a Snellen chart according to refractive values. Corneal apex, posterior elevation, corneal astigmatism values, and CCT were measured 3 times with Sirius topography (Costruzione Strumenti Oftalmici, Florence, Italy), and mean values were recorded. Intraocular pressure (IOP) was measured with a Topcon CT 80 non-contact tonometer (Topcon, Tokyo, Japan), and the corrected IOP levels were calculated by the CCT. Fundus examinations were made with a 90D lens at biomicroscopy.

Descriptive statistics such as mean along with standard deviation, minimum, maximum values and median were reported for the data. Kolmogorov-Smirnov test was used to test normality of the distributions. Mann-Whitney test was used to compare groups for quantitative variables, and for nominal variables we used chi-square test. Hypothesis test results with $p<0.05$ was considered to be statistically significant. SPSS 22.0 (SPSS, Inc., Chicago, Illinois) was used for statistical analysis.

\section{RESULTS}

A total of 30 eyes from 15 patients were included in the study. Of these 15 patients, 8 had OI Type 1, 5 had Ol Type 4, and 2 couldn't be classified by Sillence's classification. One of that patients had an FKBP10 mutation, and another one a WNT1 mutation. Mean age of the patients was $15.3 \pm 5.4$ years. Mean val- 
Table 1. Characteristics of patients.

\begin{tabular}{|c|c|c|c|c|}
\hline & Min-Max & Median & \multicolumn{2}{|c|}{ Mean士S.D/n-\% } \\
\hline Age & $8.0-29.0$ & 16.0 & \multicolumn{2}{|c|}{$15.3 \pm 5.4$} \\
\hline SE (D) & $-4.5-0.6$ & $-0,1$ & \multicolumn{2}{|c|}{$-0.5 \pm 1.2$} \\
\hline BCVA (Snellen) & $0.3-1.0$ & 1.0 & \multicolumn{2}{|c|}{$0.8 \pm 0.2$} \\
\hline СCT $(\mu \mathrm{m})$ & $397-588$ & 481 & \multicolumn{2}{|c|}{$492 \pm 67$} \\
\hline IOP (mmHG) & $9.0-22.0$ & 16.0 & \multicolumn{2}{|c|}{$16.1 \pm 2.6$} \\
\hline \multicolumn{5}{|l|}{ Blue Sclera } \\
\hline$(-)$ & & & 22 & $73.3 \%$ \\
\hline$(+)$ & & & 8 & $26.7 \%$ \\
\hline \multicolumn{5}{|l|}{ Gender } \\
\hline Female & & & 8 & $26.7 \%$ \\
\hline Male & & & 22 & $73.3 \%$ \\
\hline
\end{tabular}

ues for spherical equivalent (SE) (-0.5 $\pm 1.2 \mathrm{D}), \mathrm{BCVA}$ $(0.8 \pm 0.2)$, IOP $(16.1 \pm 2.6 \mathrm{mmHg})$ were as indicated. The lowest CCT value was $397 \mu \mathrm{m}$, and the highest value was $588 \mu \mathrm{m}$. Mean CCT was $492 \pm 67.49$ $\mu \mathrm{m}$. For 16 eyes of 8 patients, the CCT values were under $500 \mu \mathrm{m}$. Of these patients, 6 had CCT values under $450 \mu \mathrm{m}$ and 1 had a CCT value under $400 \mu \mathrm{m}$. Blue sclera was discovered in 8 eyes of 4 patients (26.7\%). All of these patients were classified as OI Type 1. Also, $50 \%$ of all of the Ol Type 1 patients had blue sclera. Characteristics of the patients are shown in Table 1.
When OI Type 1 and Type 4 patients were compared, there were no statistically significant differences in terms of age, gender, SE, IOP, or CCT values. BCVA was significantly higher in the OI Type 1 group than the OI Type 4 group ( $<<0.01$; Table 2). In our topography measurements, there was no significant difference between groups in terms of posterior elevation $(p=0.417)$ but there was a statistically significant difference in terms of corneal apex keratometry $(K)$ and corneal astigmatism values $(p<0.01, p<0.05$, respec-

Table 3. Topographic values of OI Type 1 and Type 4 patients.

\begin{tabular}{lllllll}
\hline & N Mean Median & $\begin{array}{c}\text { Std. } \\
\text { Deviation }\end{array}$ & Min. Max. \\
\hline $\begin{array}{l}\text { Type } 1 \\
\text { Corneal Apex K (D) }\end{array}$ & 1644.34 & 44.21 & 2.06 & 42 & 50 \\
\hline $\begin{array}{l}\text { Posterior } \\
\text { Elevation ( } \mu \mathrm{m})\end{array}$ & 169.44 & 9 & 2.4 & 7 & 15 \\
\hline $\begin{array}{l}\text { Corneal } \\
\text { Astigmatism (D) }\end{array}$ & 160.72 & 0.63 & 0.33 & 0.24 & 1.3 \\
\hline $\begin{array}{l}\text { Type 4 } \\
\text { Corneal Apex K (D) }\end{array}$ & 1047.99 & 47.64 & 1.76 & 46 & 51 \\
$\begin{array}{l}\text { Posterior } \\
\text { Elevation ( } \mu \text { m) }\end{array}$ & 1010 & 9.5 & 2.26 & 6 & 14 \\
\hline $\begin{array}{l}\text { Corneal } \\
\text { Astigmatism (D) }\end{array}$ & 102.03 & 2.73 & 1.20 & 0.1 & 3.15 \\
\hline K: keratometry, D: dioptry & & & & & \\
\hline
\end{tabular}

Table 2. Comparison of OI Type 1 and Type 4 patients.

\begin{tabular}{|c|c|c|c|c|c|c|c|}
\hline & \multicolumn{3}{|c|}{ Type 1} & \multicolumn{3}{|c|}{ Type 4} & \multirow[b]{2}{*}{$\mathbf{p}$} \\
\hline & Mean士S.D./n-\% & Med & (Min-Max) & Mean $\pm S . D . / n-\%$ & Med & (Min-Max) & \\
\hline Age & $14.4 \pm 3.5$ & 15.5 & 8.0- 19.0 & $12.6 \pm 3.6$ & 12 & 8- 17 & 0.337 \\
\hline SE (D) & $-0.1 \pm 0.5$ & -0.1 & $-1.4-0.6$ & $-0.3 \pm 0.8$ & 0,0 & $-1.8-0.6$ & 0.874 \\
\hline BCVA(Snellen) & $0.96 \pm 0.12$ & 1.00 & $0.66-1.00$ & $0.70 \pm 0.21$ & 0.63 & $0.50-1.00$ & 0.002 \\
\hline ССТ $(\mu \mathrm{m})$ & $461 \pm 44$ & 441 & 406- 534 & $508 \pm 79$ & 549 & 397- 588 & 0.108 \\
\hline IOP (mmHG) & $16.2 \pm 3.1$ & 16.5 & 9.0- 22.0 & $16.0 \pm 1.9$ & 16.0 & $13.0-18.0$ & 0.810 \\
\hline \multicolumn{8}{|l|}{ Gender } \\
\hline Female & $25 \%$ & & & $40 \%$ & & & 0.420 \\
\hline Male & $75 \%$ & & & $60 \%$ & & & \\
\hline \multicolumn{8}{|l|}{ Blue Sclera } \\
\hline$(-)$ & $50 \%$ & & & $100 \%$ & & & 0.007 \\
\hline$(+)$ & $50 \%$ & & & $0 \%$ & & & \\
\hline
\end{tabular}

SE: spherical equivalent, BCVA: best corrected visual acuity, CCT: central corneal thickness IOP: intraocular pressure, D:dioptry 
tively; Table 3). Corneal apex $\mathrm{K}$ and corneal astigmatism values were higher in the OI Type 4 group than the Type 1 group.

There was no significant difference in terms of posterior elevation values and corneal astigmatism values between patients with and without blue sclera ( $p=0.141, p=0.674$, respectively). Contrary to expectations, this meant that CCT was higher in the patients with blue sclera than the patients without blue sclera $(508.2 \pm 71.9 \mu \mathrm{m}$ vs. $449.3 \pm 21.1 \mu \mathrm{m})$, but the difference was not significant $(p=0.318)$. However, the corneal apex $\mathrm{K}$ value was significantly different between these two groups $(p<0.05$; Table 4$)$.

Table 3. Topographic values of OI Type 1 and Type 4 patients.

\begin{tabular}{|c|c|c|c|c|c|c|}
\hline & $\mathbf{N}$ & Mean & Median & $\begin{array}{c}\text { Std. } \\
\text { Deviation }\end{array}$ & Min. & Max. \\
\hline \multicolumn{7}{|l|}{ Blue sclera (+) } \\
\hline Pachymetry $(\mu \mathrm{m})$ & 8 & 449.3 & 441.0 & 21.1 & 428 & 482 \\
\hline Corneal Apex K (D) & 8 & 44.07 & 44.28 & 21.1 & 42 & 46 \\
\hline $\begin{array}{l}\text { Posterior } \\
\text { Elevation }(\mu \mathrm{m})\end{array}$ & 8 & 8.5 & 9 & 1.30 & 7 & 10 \\
\hline $\begin{array}{l}\text { Corneal } \\
\text { Astigmatism (D) }\end{array}$ & 8 & 0.849 & 0.83 & 0.37 & 0.38 & 1.3 \\
\hline \multicolumn{7}{|l|}{ Blue sclera (+) } \\
\hline Pachymetry $(\mu \mathrm{m})$ & 18 & 508.2 & 532.5 & 71.9 & 397 & 588 \\
\hline Corneal Apex K (D) & 18 & 46.49 & 46.64 & 2.68 & 42 & 51 \\
\hline $\begin{array}{l}\text { Posterior } \\
\text { Elevation }(\mu \mathrm{m})\end{array}$ & 18 & 10.17 & 9.5 & 2.57 & 6 & 15 \\
\hline $\begin{array}{l}\text { Corneal } \\
\text { Astigmatism (D) }\end{array}$ & 18 & 1.39 & 0.89 & 1.15 & 0.1 & 3.15 \\
\hline
\end{tabular}

K: keratometry, D: dioptry

Funduscopic examination revealed bone spicules in both eyes of a patient. Also, FKBP mutation was present, and altered electroretinogram values were compatible with retinitis pigmentosa. There was no significant retinal pathology in the fundoscopies of other patients.

\section{DISCUSSION}

The cornea and sclera consist of collagen. Therefore, it is expected to see corneal and scleral abnormalities in Ol. In their study, Heabra et al. found immature collagen structures in patients with $\mathrm{OI}(10)$. In research on postmortem tissues from 4 Ol Type 4 patients by Chan et al. and research on OI Type 3 patients by Miatz et al., it was indicated that there was a $25 \%$ decrease in collagen fiber diameters, 50\% decrease in scleral fibers, and a decrease in collagen cross linings. These authors also stated that scleral collagen alignment becomes more uniform and scleral light transmission increases, causing underlying uveal tissue to become visible, which is the reason why sclera appears to be blue in OI patients ${ }^{11,12}$.

In the present study, there were 8 eyes with blue sclera. All of these patients were in the OI Type 1 group, and $50 \%$ of OI Type 1 patients had blue sclera. In our opinion, evaluation of blue sclera in Ol patients is a subjective method, and this leads to inconsistencies in literature data. Evereklioğlu et al. compared CCT of 12 OI Type 1 patients with blue sclera and 11 Ol Type 4 patients without blue sclera with a healthy control group by using ultrasonic pachymetry. They found that in $95.6 \%$ of patients, CCT thickness was under $500 \mu \mathrm{m}$, and in $65.2 \%$ of patients, CCT thickness was under 450 $\mu \mathrm{m}$. Also, when they compared these findings with the control group, they found statistically significant thinning in Ol patients. Mean CCT in the Type 1 patients with blue sclera $(446.5 \pm 16.3 \mu \mathrm{m})$ was thinner than in the Type 4 patients without blue sclera $(473.6 \pm 25 \mu \mathrm{m})$, and this difference was statistically significant ${ }^{1}$.

In the present study, CCT was under $500 \mu \mathrm{m}$ in 16 eyes out of 30 (53\%). Mean CCT was $461 \pm 44 \mu \mathrm{m}$ in the Type 1 group and $508 \pm 79 \mu \mathrm{m}$ in Type 4 group. Mean CCT was thinner in the Type 1 group, but this difference wasn't statistically significant. Evereklioğlu et al. found no significant difference in the terms of IOP between Type 1 and Type 4 patients. However, mean IOP of OI patients $(12.7 \pm 1.8 \mathrm{mmHg})$ was lower than mean IOP of the control group $(15.6 \pm 1.9 \mathrm{mmHg})$, and this difference was statistically significant ${ }^{1}$. In the present study, 
mean IOP was $16.1 \pm 2.6 \mathrm{mmHg}$ in all of the patients: $16.2 \pm 3.1 \mathrm{mmHg}$ in Type 1 patients and $16.1 \pm 1.9 \mathrm{mmHg}$ in Type 4 patients. There was no control group in the present study, so we did not have the opportunity to compare our findings with a healthy population.

Evereklioğlu et al. compared the SE of eyes in Type 1, Type 4, and control groups and found no significant differences between them. Also, the mean refractive error was $-0.32 \pm 0.5 \mathrm{D}$, and visual acuity was between the $20 / 40$ and $20 / 20$ range in $91.3 \%$ of the patients. In our study, mean spherical equivalence was $-0.5 \pm 1.2 \mathrm{D}$, and mean BCVA was $0.8 \pm 0.2$. There was no statistically significant difference between Type 1 and Type 4 patients in term of mean spherical equivalence but BCVA was significantly higher in the Ol Type 1 group than the OI Type 4 group.

In Type 4 patients, the corneal apex $\mathrm{K}$ value was $47.99 \mathrm{D}$ and corneal astigmatism was $2.0 \mathrm{D}$. These were statistically significantly higher than in OI Type 1 patients. Lower BCVA values in the Type 4 patients could be related to this difference. However, there was no statistically significant difference in terms of CCT and posterior elevation.

In this study, CCT, corneal apex $\mathrm{K}$ value, corneal astigmatism, and posterior elevation values were lower in the patients with blue sclera than the patients without blue sclera, but only the difference in the corneal apex $\mathrm{K}$ value was statistically significant. When we evaluated all of the topographical findings, we could not reach a clear conclusion about the difference between groups regarding the risk of development up keratoconus. The low number of patients in our study was a limiting factor, so studies with higher sample sizes are needed to evaluate the relationship between corneal ectasia and blue sclera.

\section{CONCLUSION}

In addition to blue sclera, plenty of ophthalmological findings can be seen in Ol patients. One of the most important finding in Ol is thinning in the CCT. Therefore, ophthalmologists should be cautious about un- derestimation of the IOP. CCT must be considered in Ol patients who are candidates for refractive surgery. Patients should be warned about the use of protective glasses to prevent ocular traumas because eye rupture can occur more easily than in healthy patients and cause serious morbidities. Our findings in patients with OI were steep $\mathrm{K}$ values especially in Type 4 group.So patients should be followed up regularly for keratoconus.

\section{REFERENCES}

1. Evereklioglu C, Madenci E, Bayazit YA, Yilmaz K, Balat A, Bekir NA. Central corneal thickness is lower in osteogenesis imperfecta and negatively correlates the presence of blue sclera. Ophthalmic Physiol Opt 2002;22(6):511-5. https://doi.org/10.1046/j.1475-1313.2002.00062.x

2. ion VM, Billet E. Musculoskeletal disorders. In: Duane TD, ed. Clinical Ophthalmology. Philadelphia: Harper and Row Publishers; 1986:15-6.

3. Butani L, Rosekrans JA, Morgenstern BZ, Milliner DS. An unusual renal complication in a patient with osteogenesis imperfecta. Am J Kidney Dis. 1995;25(3):489-91. https://doi.org/10.1016/0272-6386(95)90114-0

4. Sillence DO, Senn A, Danks DM. Genetic heterogeneity in osteogenesis imperfecta. J Med Genet. 1979;16(2):101-16. https://doi.org/10.1136/jmg.16.2.101

5. Shaker JL, Albert C, Fritz J, Harris G. Recent developments in osteogenesis imperfecta. F1000Res 2015; 4(F1000 Faculty Rev):681. https://dx.doi.org/10.12688\%2Ff1000research.6398.1

6. Kaiser-Kupfer MI, McCain L, Shapiro JR, Podgor MJ, Kupfer C, Rowe D. Low ocular rigidity in patients with osteogenesis imperfecta. Invest Ophthalmol Vis Sci. 1981;20(6):807-9.

7. Beckh U, Schönherr U, Naumann GO. Autosomal dominant keratoconus as the chief ocular symptom in Lobstein osteogenesis imperfecta tarda. Klinische Monatsblatter fur Augenheilkunde 1995;206(4):268-72.

https://doi.org/10.1055/s-2008-1035438

8. Natarajan R, Shah GY, Rao SK, Padamanabhan P. Penetrating keratoplasty as a globe-saving procedure in fragile cornea. Cornea 2003;22(2):164-5. https://doi.org/10.1097/00003226-200303000-00017

9. Ozturk G, Pınarcı E, Hekimhan P, Yılmaz OF. Osteogenesisimperfekta Tip 1 hastalığı bulunan olguda minör travma sonucu gelişen korneal rüptüre yaklaşım. Turk J Ophthalmol. 2007;37:69-72.

10. Haebara H, Yamasaki Y, Kyogoku M. An autopsy case of osteogenesis imperfecta congenita: Histochemical and electron microscopical studies. Acta Pathol Jpn. 1969;19(3):377-94. https://doi.org/10.1111/j.1440-1827.1969.tb00713.x

11. Chan CC, Green WR, de la Cruz ZC, Hillis A. Ocular findings in osteogenesis imperfecta congenita. Arch Ophthalmol. 1982; 100(9):1458-63. https://doi.org/10.1001/archopht.1982.01030040437014

12. Mietz H, Kasner L, Green WR. Histopathologic and electronmicroscopic features of corneal and scleral collagen fibers in osteogenesis imperfecta type III. Graefes Arch Clin Exp Ophthalmol. 1997;235(7):405-10. https://doi.org/10.1007/BF00947058 